\title{
Efek Mediasi Motivasi Atas Hubungan Etos Kerja Terhadap Kinerja Pegawai Dinas Kehutanan UPT. Kesatuan Pengelolaan Hutan Wilayah II Pematangsiantar
}

\author{
Marthin Hutler Ambarita
}

Sekolah Tinggi Ilmu Ekonomi Sultan Agung marthinambarita@stiesultanagung.ac.id

\section{Sudung Simatupang}

Sekolah Tinggi Ilmu Ekonomi Sultan Agung

sudungsimatupang@stiesultanagung.ac.id

\section{Vivi Candra}

Sekolah Tinggi Ilmu Ekonomi Sultan Agung vivicandra018@gmail.com

\begin{abstract}
Abstrak The purpose of this study was to determine the description of motivation, work ethic and employee performance at the Forest Service Unit of UPT. Forest Management Unit Region II Pematangsiantar and to determine the effect of motivation on the relationship of work ethic on employee performance at the Forest Service Unit of UPT. Forest Management Unit Region II Pematangsiantar. This research uses the design of library research and field research. The population in this study were UPT Forest Service employees. The Pematangsiantar Region II Forest Management Unit totaling 67 employees. The type of data used is qualitative and quantitative data. Data sources used are primary data and secondary data. Data collection is done by questionnaire, interview and documentation. The analysis technique used is the classic assumption test with validity, reliability and normality tests, qualitative descriptive analysis and quantitative descriptive analysis with path analysis and hypothesis testing. The results of the study concluded that the work ethic has a significant effect on employee performance. Motivation has a significant effect on employee performance and motivation is able to mediate the relationship of work ethics on employee performance.
\end{abstract}

Kata Kunci motivation, work ethic, employee perfomance

\section{PENDAHULUAN}

Keberhasilan suatu organisasi atau lembaga dalam mencapai tujuannya tidak lepas dari sumber daya manusia yang dimiliki. Sumber daya manusia adalah salah satu faktor penting dalam pencapaian tujuan sebuah organisasi sehingga organisasi maupun lembaga 
harus memiliki sumber daya manusia yang berkompeten dan memiliki tingkat kinerja yang tinggi dalam menjalankan tugas-tugas yang dibebankan oleh organisasi. Dinas Kehutanan Unit Pelayanan Terpadu (UPT) Kesatuan Pengelolaan Hutan Wilayah II Pematangsiantar yang berlokasi di jalan Gunung Simanuk-manuk No. 9 merupakan instansi pemerintah yang bergerak dalam bidang pengelolaan hasil hutan baik barang maupun jasa secara lestari (jangka panjang) dengan memperhatikan kelestarian usaha dan keseimbangan lingkungan, sosial, ekonomi dan budaya masyarakat setempat yang dibentuk berdasarkan Peraturan Gubernur Provinsi Sumatera Utara No. 38 Tahun 2016 tentang pembentukan Dinas-dinas Daerah Provinsi Sumatera Utara dimana dalam Peraturan Gubernur tersebut terbentuk UPT. KPH Wilayah II Pematangsiantar.

Pembelajaran dalam organisasi melibatkan individu itu sendiri, mereka membuat perubahan dari pemikiran organisasi tradisional ke organisasi pembelajaran, dalam mengembangkan kemampuan baik secara kreatif maupun secara kritis (Sahir, et al. 2020). Kinerja merupakan hasil kerja yang dicapai oleh seorang pegawai yang merujuk pada prestasi kerja pegawai. Standar kinerja pegawai pada Dinas Kehutanan UPT. Kesatuan Pengelolaan Hutan Wilayah II Pematangsiantar telah diatur dalam PP No. 46 tahun 2011, yaitu Sasaran Kerja Pegawai (SKP) dengan indikator kualitas, kuantitas, biaya dan waktu. Sedangkan pada Perilaku Kerja (PK) memiliki indikator orientasi pelayanan, integritas, komitmen, disiplin, kerjasama dan kepemimpinan. Implikasi kinerja pegawai memiliki relevansi dengan citra instansi, maka dari itu perlu adanya perhatian khusus dari instansi dalam meningkatkan performa seorang pegawai (Mamminanga, 2019). Pada dimensi Sasaran Kerja Pegawai (SKP), berdasarkan hasil wawancara pra survei pada beberapa pegawai terdapat $20 \%$ pegawai yang kurang memanfaatkan waktu bekerja secara optimal sehingga belum mampu mencapai target kerja dengan tepat waktu. Kemudian pada dimensi Perilaku Kerja (PK) terdapat $20 \%$ hal ini terlihat dari jam kehadiran pegawai di pagi hari masih ada pegawai yang melewatkan jadwal apel pagi yang dilakukan setiap hari senin bahkan tidak mengikutinya.

Representatif motivasi yang baik akan mendorong keinginan yang ada dalam diri seseorang untuk melakukan sautu pekerjaan (Syahputra, Bahri, \& Rambe, 2020). Secara umum tingkat motivasi yang rendah akan menyebabkan pencapaian intensitas pekerjaan yang rendah pula (Mianto, Hendriani, \& Efni, 2018). Fenomena yang terjadi pada Dinas Kehutanan UPT. Kesatuan Pengelolaan Hutan Wilayah II Pematangsiantar terjadi pada dimensi kebutuhan akan prestasi, dimana masih terdapat beberapa pegawai yang kurang bersemangat dalam pencapaian prestasi kerja secara maksimal sehingga hasil yang dicapai tidak mengalami peningkatan. Sedangkan pada dimensi kebutuhan akan afiliasi, dapat dilihat dari masih terdapat beberapa pegawai yang kurang sigap dalam memberikan pelayanan yang terbaik kepada masyarakat.

Seseorang yang memiliki tingkat etos kerja yang rendah akan berimplikasi pada beberapa aspek seperti ekonomi dan sosial. Cerminan etos kerja yang baik akan mencerminkan tingkat kinerja yang baik pula, sehingga perlu ada stimulus untuk menjaga etos kerja seseorang dalam keadaan baik dan normal (Herlina, Sedjati, \& Wartubi, 2019). Fenomena etos kerja pegawai Dinas Kehutanan UPT. Kesatuan Pengelolaan Hutan Wilayah II Pematangsiantar terjadi pada dimensi keinginan untuk mandiri, dimana masih terdapat pegawai yang tidak memiliki inisiatif dalam melakukan pekerjaan secara maksimal seperti menunda-nunda pekerjaan sehingga target yang ditentukan tidak tercapai dengan baik. Sedangkan pada dimensi penyesuaian diri, masih terdapat beberapa pegawai yang kurang mampu menyesuaikan diri dengan rekan sekerjanya karena merasa minder. 


\section{LANDASAN TEORI}

\section{Motivasi}

Motivasi kerja adalah penciptaaan daya pendorong yang dapat mengakibatkan seseorang untuk berbuat atau melakukan sesuatu untuk mencapai tujuan yang diinginkan (Putra \& Prasetya, 2018). Motivasi merupakan suatu proses psikologis yang mencerminkan antar sikap, kebutuhan, persepsi dan kebutuhan yang terjadi pada diri seseorang. Menurut Luthans (2006), motivasi merupakan keadaan dalam diri individu yang memunculkan, mengarahkan dan mempertahankan perilaku. Indikator motivasi yang digunakan terdiri dari, yaitu kebutuhan akan prestasi, kebutuhan akan afiliasi dan kebutuhan akan kekuasaan (Mc Clelland dalam Robbins dan Timothy, 2008).

\section{Etos Kerja}

Peningkatan etos kerja yang konsisten dan ditangani secara terpadu oleh instansi tentunya memerlukan keahlian secara interpersonal (Herlina et al., 2019). Etos kerja adalah seperangkat perilaku kerja positif yang berakar pada kerjasamayang kental, keyakinan yang fundamental, disertai komitmen yang totapada paradigm kerja yang integral (Simanjuntak, 2020). Seseorang harus memiliki pandangan dan sikap menghargai kerja sebagai sesuatu yang luhur untuk eksistensi manusia. Suatu pandangan dan sikap terhadap kerja dikenal dengan istilah etos kerja. Menurut Anoraga (2009), etos kerja merupakan suatu pandangan dan sikap suatu bangsa atau umat terhadap kerja. Adapun dimensi etos kerja yaitu menghargai waktu, tangguh dan pantang menyerah, keinginan untuk mandiri (independent) dan penyesuaian diri (Tasmara, 2002).

\section{Kinerja Pegawai}

Kinerja adalah bagian dari produktivitas kerja, produktivitas berasal dari kata "produktif" artinya sesuatu yang mengandung kemampuan untuk digali, sehingga produktivitas dapat disebut suatu proses kegiatan yang terstruktur guna menggali potensi yang ada dalam sebuah komoditi atau objek. Kinerja dalam organisasi merupakan jawaban dan berhasil atau tidaknya tujuan organisasi yang telah ditetapkan. )". Menurut Mondy (2008:256), "kinerja ialah suatu proses yang berorientasi pada tujuan yang diarahkan untuk memastikan bahwa proses-proses keorganisasian ada pada tempatnya untuk memaksimalkan produktivitas para pegawai, tim dan akhirnya organisasi". Presiden Republik Indonesia telah menetapkan peraturan mengenai Sasaran Kerja Pegawai (SKP) yaitu Peraturan Pemerintah Republik Indonesia Nomor 46 Tahun 2011 Tentang Penilaian Prestasi Kerja Pegawai Negeri Sipil. Penilaian prestasi kerja tersebut terdiri dari dua unsur yaitu Sasaran Kerja Pegawai (SKP) dan Perilaku Kerja (PK) dengan bobot penilaian masing-masing unsur Sasaran Kerja Pegawai (SKP) 60\% dan Perilaku Kerja sebesar $40 \%$.

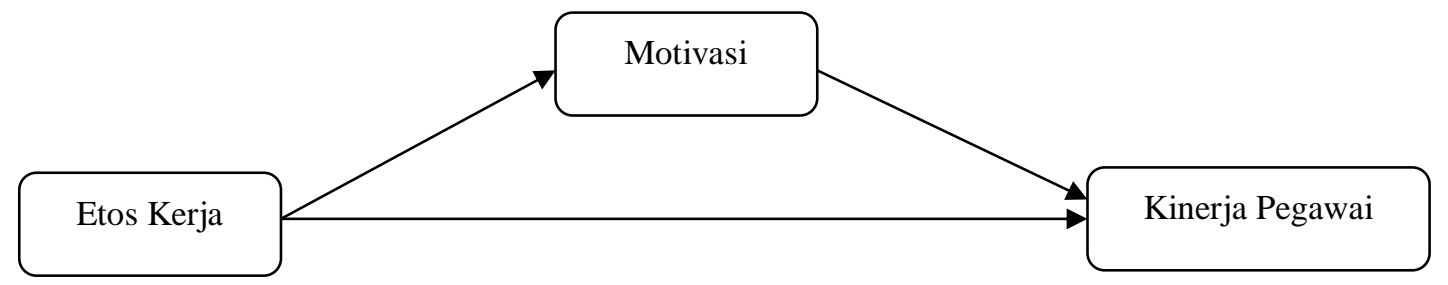

Gambar 1. Kerangka Pemikiran 


\section{METODOLOGI PENELITIAN}

Desain penelitian menggunakan pendekatan kepustakaan dan lapangan. Populasi dan sampel pada penelitian ini adalah pegawai Dinas Kehutanan UPT. Kesatuan Pengelolaan Hutan Wilayah II Pematangsiantar yang berjumlah 67 orang pegawai. Jenis data yang digunakan yaitu data kualitatif dan kuantitatif. Sumber data yang digunakan adalah data primer dan data sekunder. Pengumpulan data dilakukan dengan kuesioner, wawancara dan dokumentasi. Teknik analisis yang digunakan adalah uji asumsi klasik dengan uji validitas, uji reliablitas dan uji normalitas menggunakan software spss analisis deskriptif kualitatif dan analisis deskriptif kuantitatif dengan regresi linier berganda, analisis koefisien korelasi, koefisien determinasi dan uji hipotesis menggunakan software spss.

\section{HASIL PENELITIAN}

\section{Uji Validitas}

Tabel 1. Hasil Uji Validitas

\begin{tabular}{|c|c|c|c|}
\hline $\begin{array}{l}\text { Keterangan } \\
\text { Variabel }\end{array}$ & Indikator Variabel & Hasil r hitung & Kesimpulan \\
\hline \multirow[t]{3}{*}{ Motivasi } & $\begin{array}{l}\text { Kebutuhan akan } \\
\text { prestasi }\end{array}$ & 0,486 & Valid \\
\hline & $\begin{array}{l}\text { Kebutuhan akan } \\
\text { affiliasi }\end{array}$ & 0,564 & Valid \\
\hline & $\begin{array}{l}\text { Kebutuhan akan } \\
\text { kekuasaan }\end{array}$ & 0,572 & Valid \\
\hline \multirow{4}{*}{ Etos Kerja } & Menghargai waktu & 0,510 & Valid \\
\hline & $\begin{array}{l}\text { Tangguh dan pantang } \\
\text { menyerah }\end{array}$ & 0,493 & Valid \\
\hline & $\begin{array}{l}\text { Keinginan untuk } \\
\text { mandiri }\end{array}$ & 0,441 & Valid \\
\hline & Penyesuaian diri & 0,522 & Valid \\
\hline \multirow[t]{2}{*}{ Kinerja Pegawai } & $\begin{array}{ll}\text { Sasaran } & \text { kinerja } \\
\text { pegawai } & \\
\end{array}$ & 0,596 & Valid \\
\hline & Perilaku kerja & 0,575 & Valid \\
\hline
\end{tabular}

Sumber: Olahan Data SPSS (2019)

Berdasarkan pengujian validitas pada tabel 1 di atas, diketahui bahwa nilai $r_{\text {hitung }}$

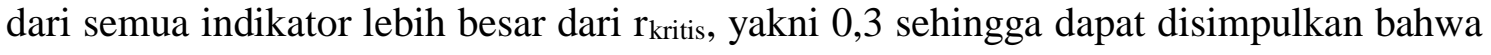
semua indikator penelitian adalah valid.

\section{Uji Reliabilitas}

Tabel 2. Hasil Uji Reliabilitas

\begin{tabular}{|l|l|l|l|}
\hline $\begin{array}{l}\text { Keterangan } \\
\text { Variabel }\end{array}$ & Indikator Variabel & Hasil r hitung & Kesimpulan \\
\hline Motivasi & $\begin{array}{l}\text { Kebutuhan akan } \\
\text { prestasi }\end{array}$ & 0,931 & Reliabel \\
\hline
\end{tabular}




\begin{tabular}{|c|c|c|c|}
\hline & $\begin{array}{l}\text { Kebutuhan akan } \\
\text { affiliasi }\end{array}$ & 0,936 & Reliabel \\
\hline & $\begin{array}{l}\text { Kebutuhan akan } \\
\text { kekuasaan }\end{array}$ & 0,938 & Reliabel \\
\hline \multirow{4}{*}{ Etos Kerja } & Menghargai waktu & 0,924 & Reliabel \\
\hline & $\begin{array}{l}\text { Tangguh dan pantang } \\
\text { menyerah }\end{array}$ & 0,930 & Reliabel \\
\hline & $\begin{array}{l}\text { Keinginan untuk } \\
\text { mandiri }\end{array}$ & 0,926 & Reliabel \\
\hline & Penyesuaian diri & 0,922 & Reliabel \\
\hline \multirow[t]{2}{*}{ Kinerja Pegawai } & $\begin{array}{l}\text { Sasaran } \\
\text { pegawai }\end{array}$ & 0,942 & Reliabel \\
\hline & Perilaku kerja & 0,953 & Reliabel \\
\hline
\end{tabular}

Sumber: Olahan Data SPSS (2019)

Berdasarkan hasil pengujian menggunakan SPSS, maka pada tabel 2 hasil uji reliabilitas menunjukkan bahwa semua indikator dari variabel Cronbach's Alpha if Item Deleted lebih besar dari 0,70. Hal ini berarti indikator dari variabel dalam penelitian ini adalah reliabel.

\section{Uji Normalitas}

Tabel 3. Hasil Uji Normalitas

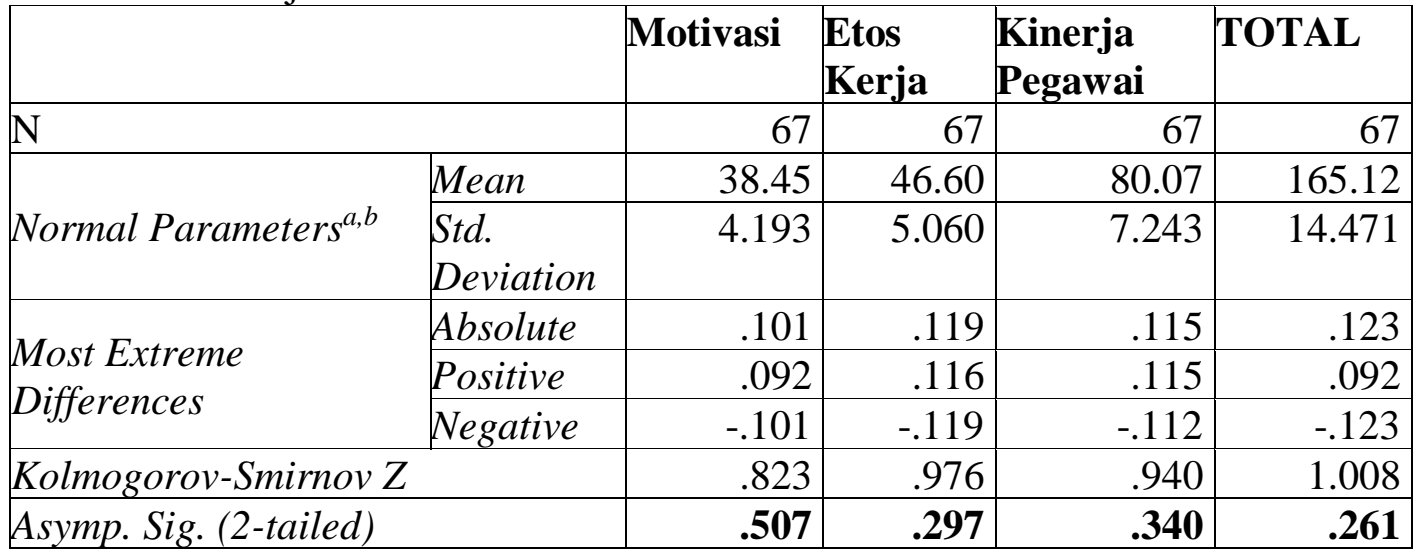

Sumber: Olahan Data SPSS (2019)

Berdasarkan tabel 3 di atas, terlihat uji normalitas One-Sample Kolmogorov Smirnov Test di atas dapat dilihat Asymp. Sig (2-tailed) pada total $\mathrm{X}_{1}$ (motivasi) sebesar 0,507, total $\mathrm{X}_{2}$ (etos kerja) 0,297 dan total Y (kinerja pegawai) sebesar 0,340 serta total keseluruhan 0,261 memiliki Asymp.Sig (2-tailed) lebih besar dari alpha 0,05. Dengan demikian dapat dinyatakan bahwa data dari masing-masing variabel berdistribusi normal

\section{Analisis Deskriptif Kualitatif}

Tabel 4. Rekapitulasi Persepsi Responden

\begin{tabular}{|l|l|l|l|}
\hline $\begin{array}{l}\text { Keterangan } \\
\text { Variabel }\end{array}$ & Indikator Variabel & $\begin{array}{l}\text { Nilai Rata-Rata } \\
\text { Persepsi Responden }\end{array}$ & $\begin{array}{l}\text { Kriteria } \\
\text { Jawaban }\end{array}$ \\
\hline Motivasi & $\begin{array}{l}\text { Kebutuhan akan } \\
\text { prestasi }\end{array}$ & 3,72 & Tinggi \\
\hline
\end{tabular}




\begin{tabular}{|c|c|c|c|}
\hline & $\begin{array}{l}\text { Kebutuhan akan } \\
\text { affiliasi }\end{array}$ & 3,65 & Tinggi \\
\hline & $\begin{array}{l}\text { Kebutuhan akan } \\
\text { kekuasaan }\end{array}$ & 3,86 & Tinggi \\
\hline \multirow{4}{*}{ Etos Kerja } & Menghargai waktu & 4,08 & Baik \\
\hline & $\begin{array}{l}\text { Tangguh dan pantang } \\
\text { menyerah }\end{array}$ & 3,94 & Baik \\
\hline & $\begin{array}{l}\text { Keinginan untuk } \\
\text { mandiri }\end{array}$ & 3,75 & Baik \\
\hline & Penyesuaian diri & 3,69 & Baik \\
\hline \multirow[t]{2}{*}{ Kinerja Pegawai } & $\begin{array}{ll}\text { Sasaran } & \text { kinerja } \\
\text { pegawai } & \\
\end{array}$ & 3,82 & Baik \\
\hline & Perilaku kerja & 3,91 & Baik \\
\hline
\end{tabular}

Sumber: Olahan Data (2019)

Hasil analisis deskriptif kualitatif pada Dinas Kehutanan UPT. Kesatuan Pengelolaan Hutan Wilayah II Pematangsiantar tentang motivasi memperoleh kategori jawaban tinggi. Secara keseluruhan jawaban responden mengenai motivasi mendapat nilai rata-rata sebesar 3,84 dengan kriteria tinggi. Kemudian nilai rata-rata tertinggi sebesar 4,10 dengan kriteria jawaban tinggi untuk dimensi kebutuhan akan prestasi pada indikator usaha dalam mencari pengetahuan untuk prestasi kerja yang maksimal. Sedangkan nilai rata-rata terendah sebesar 3,37 dengan kriteria jawaban cukup tinggi untuk dimensi kebutuhan akan prestasi pada indikator semangat bekerja untuk mencapai kinerja yang maksimal dan dimensi kebutuhan akan afiliasi pada indikator hasil pelayanan dalam mendapatkan apresiasi pimpinan.

Hasil analisis deskriptif kualitatif tentang etos kerja pada Dinas Kehutanan UPT. Kesatuan Pengelolaan Hutan Wilayah II Pematangsiantar memperoleh kategori jawaban baik. Secara keseluruhan jawaban responden mengenai etos kerja mendapat nilai rata-rata sebesar 3,88 dengan kriteria baik. Kemudian nilai rata-rata tertinggi sebesar 4,12 dengan kriteria baik untuk dimensi menghargai waktu pada indikator mempergunakan waktu . Sedangkan nilai rata-rata terendah sebesar 3,36 dengan kriteria cukup baik pada dimensi keinginan untuk mandiri pada indikator inisiatif dalam bekerja secara maksimal untuk mencapai sasaran kerja dan dimensi penyesuaian diri pada indikator menyesuaikan diri dalam bekerja dengan atasan di kantor.

Hasil analisis deskriptif kualitatif tentang kinerja pegawai pada Dinas Kehutanan UPT. Kesatuan Pengelolaan Hutan Wilayah II Pematangsiantar memperoleh kategori jawaban baik. Secara keseluruhan dapat dilihat bahwa total jawaban responden mengenai kinerja pegawai memperoleh nilai rata-rata sebesar 4,00 dengan kriteria jawaban baik. Nilai ratarata tertinggi sebesar 4,33 dengan kriteria jawaban sangat baik pada dimensi perilaku kerja dengan indikator loyalitas dalam bekerja, tanggung jawab dalam bekerja, kepatuhan dalam menaati Peraturan Perundang-undangan, hubungan kerjasama dengan atasan, kemampuan pimpinan memotivasi bawahannya dan kemampuan pimpinan mengarahkan bawahannya. Sedangkan nilai rata-rata terendah sebesar 3,33 dengan kriteria jawaban cukup baik pada dimensi sasaran kerja pegawai dengan indikator ketepatan waktu dalam menyelesaikan tugas yang diberikan dan dimensi perilaku kerja dengan indikator tingkat kehadiran dalam bekerja.

\section{Analisis Deskriptif Kuantitatif}




\section{Persamaan Struktural Pertama}

Untuk mengetahui dan membuktikan bahwa ada pengaruh variabel etos kerja sebagai variabel bebas terhadap kinerja pegawai sebagai variabel terikat, maka digunakan analisis persamaan struktural pertama yang disajikan pada tabel berikut ini.

Tabel 5. Hasil Analisis Jalur Persamaan Struktural Pertama

\begin{tabular}{|c|c|c|c|c|c|}
\hline \multirow[t]{2}{*}{ Model } & \multicolumn{2}{|c|}{$\begin{array}{l}\text { Unstandardized } \\
\text { Coefficients }\end{array}$} & \multirow{2}{*}{$\begin{array}{l}\text { Standardize } \\
\text { d } \\
\text { Coefficients } \\
\text { Beta }\end{array}$} & \multirow[t]{2}{*}{$\mathbf{t}$} & \multirow[t]{2}{*}{ Sig. } \\
\hline & B & Std. Error & & & \\
\hline $1 \quad$ (Constant) & 17.464 & 4.044 & & 4.319 & .000 \\
\hline Etos Kerja & .450 & .086 & .543 & 5.219 & .000 \\
\hline
\end{tabular}

Sumber: Olahan Data SPSS (2019)

Tabel 6. Koefisien Korelasi dan Koefisien Determinasi

\begin{tabular}{|c|c|c|c|}
\hline Model & $\mathbf{R}$ & R Square & Adjusted R Square \\
\hline 1 & .543 & .295 & .284 \\
\hline
\end{tabular}

Sumber: Olahan Data SPSS (2019)

Berdasarkan hasil tabel 6 di atas, diketahui nilai error tem (e) sebesar 0,840 yang artinya etos kerja mampu mempengaruhi mtovasi kerja sebesar $84 \%$ dan sisanya dipengaruhi oleh faktor lain diluar penelitian. Selanjuttnya pada tabel 5 diketahui nilai standardized coefficients beta $=0,543$ dan signifikansi sebesar $0,000 \leq 0,05$, maka dapat disimpulkan bahwa etos kerja berpengaruh signifikan. Langkah selanjutnya adalah membuktikan analisis jalur kedua, yakni bahwa ada pengaruh etos kerja terhadap kinerja dengan motivasi sebagai variabel mediasi yang disajikan pada tabel berikut ini.

Tabel 7. Hasil Analisis Jalur Persamaan Struktural Pertama

\begin{tabular}{|c|c|c|c|c|c|}
\hline \multirow[t]{2}{*}{ Model } & \multicolumn{2}{|c|}{$\begin{array}{l}\text { Unstandardized } \\
\text { Coefficients }\end{array}$} & \multirow{2}{*}{$\begin{array}{l}\text { Standardize } \\
\text { d } \\
\text { Coefficients } \\
\text { Beta }\end{array}$} & \multirow[t]{2}{*}{$\mathbf{t}$} & \multirow[t]{2}{*}{ Sig. } \\
\hline & $\bar{B}$ & Std. Error & & & \\
\hline $1 \quad$ (Constant) & 21.355 & 5.921 & & 3.606 & .000 \\
\hline Etos Kerja & .474 & .133 & .331 & 3.570 & .001 \\
\hline Motivasi & .953 & .160 & .552 & 5.954 & .000 \\
\hline
\end{tabular}

Sumber: Olahan Data SPSS (2019)

Tabel 8. Koefisien Korelasi dan Koefisien Determinasi

\begin{tabular}{llllll}
\hline Model & R & & R Square & & Adjusted R Square \\
\\
\hline 1 & .783 & & .613 & & .600 \\
\hline
\end{tabular}

Sumber: Olahan Data SPSS (2019)

Berdasarkan hasil tabel 8 di atas, diketahui nilai error tem (e) sebesar 0,622 yang artinya etos kerja dan motivasi mampu mempengaruhi mtovasi kerja sebesar $62,2 \%$ dan sisanya dipengaruhi oleh faktor lain diluar penelitian. Selanjuttnya pada tabel 7 diketahui nilai 
standardized coefficients beta $=0,331$ dan signifikansi sebesar $0,001 \leq 0,05$, maka dapat disimpulkan bahwa etos kerja berpengaruh signifikan terhadap kinerja. Kemudian nilai standardized coefficients beta $=0,552$ dan signifikansi sebesar $0,000 \leq 0,05$, maka dapat disimpulkan bahwa motivasi berpengaruh signifikan terhadap kinerja. Lebih lanjut berdasarkan hasil dari koefisien jalur pada analisis jalur di atas, maka representatif hubungan kausal antar variabel etos kerja, motivasi dan kinerja pegawai dapat digambarkan dengan hubungan langsung dan tidak langsung yang dirangkum pada tabel berikut ini.

Tabel 9. Pengaruh Langsung dan Tidak Langsung Antar Variabel

\begin{tabular}{|l|l|l|l|}
\hline Pengaruh Variabel & Pengaruh Langsung & $\begin{array}{l}\text { Pengaruh Tidak } \\
\text { Langsung Melalui } \\
\text { Motivasi }\end{array}$ & Total Pengaruh \\
\hline $\begin{array}{l}\text { Etos Kerja }>> \\
\text { Motivasi }\end{array}$ & 0.543 & 0.428 & 0.543 \\
\hline $\begin{array}{l}\text { Etos Kerja }>> \\
\text { Kinerja }\end{array}$ & 0.331 & 0.731 \\
\hline $\begin{array}{l}\text { Motivasi >> } \\
\text { Kinerja }\end{array}$ & 0.552 & 0.552 \\
\hline
\end{tabular}

Sumber: Olahan Data SPSS (2019)

Berdasarkan hasil tabel 9 di atas, diketahui pengaruh langsung etos kerja terhadap motivasi sebesar 0.543. Pengaruh langsung etos kerja terhadap kinerja sebesar 0.331 dan pengaruh motivasi terhadap kinerja sebesar 0.552. Selanjutnya pengaruh tidak langsung etos kerja terhadap kinerja dengan motivasi sebagai mediasi bernilai 0.428 . Berdasarkan analisis data di atas, maka dapat disimpulkan bahwa nilai pengaruh tidak lansung etos kerja terhadap kinerja lebih besar daripada pengaruh langsung, sehingga dalam hal ini motivasi dianggap mampu memediasi hubungan etos kerja terhadap kinerja.

\section{PEMBAHASAN}

\section{Pengaruh Etos Kerja Terhadap Motivasi}

$\mathrm{H}_{0} \quad$ : Tidak ada pengaruh yang signifikan dari etos kerja terhadap motivasi

$\mathrm{H}_{1} \quad$ : Ada pengaruh yang signifikan dari etos kerja terhadap motivasi

Kesimpulan: Karena hasil nilai thitung sebesar $5.954 \geq 1.96$ dan nilai P sebesar $0.000<$ 0.05 maka dapat disimpulkan $\mathrm{H}_{0}$ ditolak dan $\mathrm{H}_{1}$ diterima yang berarti ada pengaruh yang signifikan antara etos kerja terhadap motivasi.

Hasil penelitian ini menunjukkan bahwa etos kerja berpengaruh positif dan signifikan terhadap motivasi. Hasil ini membuktikan bahwa manifestasi motivasi yang tinggi tercermin dari tingkat etos kerja seseorang dalam menyelesaikan intensitas pekerjaannya. Etos kerja memiliki relevansi terhadap tingkat motivasi seseorang dalam meningkatkan performa hasil pekerjaannya. Hasil penelitian ini sejalan dengan hasil penelitian yang dilakukan oleh (Takwim, 2012), (I Gede Ardana, I Nyoman Natajaya, 2015), (Ritonga, 2019).

\section{Pengaruh Etos Kerja Terhadap Kinerja}

$\mathrm{H}_{0} \quad$ : Tidak ada pengaruh yang signifikan dari etos kerja terhadap kinerja pegawai 
$\mathrm{H}_{2}$ : Ada pengaruh yang signifikan dari etos kerja terhadap kinerja pegawai

Kesimpulan: Karena hasil nilai thitung sebesar $3.570 \geq 1.96$ dan nilai $\mathrm{P}$ sebesar $0.001<$ 0.05 maka dapat disimpulkan $\mathrm{H}_{0}$ ditolak dan $\mathrm{H}_{2}$ diterima yang berarti ada pengaruh yang signifikan antara etos kerja terhadap kinerja pegawai.

Hasil penelitian ini menunjukkan bahwa etos kerja berpengaruh positif dan signifikan terhadap kinerja pegawai. Hasil ini membuktikan bahwa etos kerja yang dikelola dengan baik dan konsisten, akan berdampak pada tingkat kinerja seseorang dalam melakukan pekerjaan. Pegawai yang memiliki etos kerja yang tinggi tercermin dari perilakunya seperti suka bekerja keras, religius, tidak membuang-buang waktu selama jam bekerja. Hasil penelitian ini sejalan dengan hasil penelitian (Rosmawati \& Jermawinsyah, 2018), (Lie, Sherly, Dharma, \& Sudirman, 2019), (Herlina et al., 2019), (Andriani, 2018), (Simanjuntak, 2020).

\section{Pengaruh Motivasi Terhadap Kinerja}

$\mathrm{H}_{0} \quad$ : Tidak ada pengaruh yang signifikan dari motivasi terhadap kinerja pegawai

$\mathrm{H}_{2}$ : Ada pengaruh yang signifikan dari motivasi terhadap kinerja pegawai

Kesimpulan: Karena hasil nilai thitung sebesar $5.954 \geq 1.96$ dan nilai P sebesar $0.000<$ 0.05 maka dapat disimpulkan $\mathrm{H}_{0}$ ditolak dan $\mathrm{H}_{2}$ diterima yang berarti ada pengaruh yang signifikan antara motivasi terhadap kinerja pegawai.

Hasil penelitian ini menunjukkan bahwa motivasi berpengaruh positif dan signifikan terhadap kinerja pegawai. Motivasi merupakan suatu hal yang dapat meningkatkan hasil kerja seseorang. Dengan diberikannya motivasi maka karyawan yang bekerja pada perusahaan tersebut dapat berguna dan juga membantu perusahaan untuk mencapai tujuan yang telah ditetapkan. Motivasi merupakan salah satu stimulus yang dimiliki seseorang untuk mempengaruhi tingkat kinerjanya. Hasil penelitian ini sejalan dengan hasil penelitian (Syahputra et al., 2020), (Candra, Silaban, \& Sudirman, 2019), (Sah, Mulyasa, \& Hanafiah, 2018), (Putra \& Prasetya, 2018), (Mianto et al., 2018), (Azis, 2018).

\section{KESIMPULAN}

Hasil analisis deskriptif kualitatif pada Dinas Kehutanan UPT. Kesatuan Pengelolaan Hutan Wilayah II Pematangsiantar tentang motivasi memperoleh kategori jawaban tinggi. Hasil analisis deskriptif kualitatif tentang etos kerja pada Dinas Kehutanan UPT. Kesatuan Pengelolaan Hutan Wilayah II Pematangsiantar memperoleh kategori jawaban baik. Hasil analisis deskriptif kualitatif tentang kinerja pegawai pada Dinas Kehutanan UPT. Kesatuan Pengelolaan Hutan Wilayah II Pematangsiantar memperoleh kategori jawaban baik. Hasil uji hipotesis variabel etos kerja terhadap motivasi berpengaruh signifikan, kemudian hasi hipotesis etos kerja terhadap kinerja berpengaruh signifikan dan hasil hipotesis motivasi terhadap kinerja berpengaruh signifikan. Lebih lanjut berdasarkan hasil penelitian, motivasi dinyatakan mampu memediasi hubungan antara etos kerja terhadap kinerja.

\section{DAFTAR PUSTAKA}

Andriani, M. (2018). Pengaruh Etos Kerja dan Kedisplinan Terhadap Kinerja Karyawan. Jurnal Manajemen Dan Kewirausahaan, 3(1), 25-32. 
Anoraga, Panji. 2001. Psikologi Kerja. Jakarta. PT. Rineka Cipta.

Azis, M. D. (2018). Pengaruh Kompetensi, Motivasi, dan Gaya Kepemimpinan Terhadap Kinerja Pegawai pada Kantor Pelayanan Pajak Pratama Makassar Selatan. Jurnal Aplikasi Manajemen, Ekonomi Dan Bisnis, 2(2), 12-22.

Candra, V., Silaban, P., \& Sudirman, A. (2019). Pengaruh Gaya Kepemimpinan Kepala Sekolah dan Budaya Sekolah terhadap Kinerja Guru. Harmoni Sosial: Jurnal Pendidikan IPS, 6(1), 49-60. https://doi.org/10.33753/mandiri.v3i2.85

Herlina, E., Sedjati, R. S., \& Wartubi. (2019). Pengaruh Etos Kerja, Kepuasan Kerja dan Lingkungan Kerja Terhadap Kinerja Pegawai di Puskesmas Karangampel Kabupaten Indrimayu. Jurnal Manajemen, 2(3), 228-237.

I Gede Ardana, I Nyoman Natajaya, I. G. K. A. S. (2015). Determinasi Persepsi Guru Pada Kepemimpinan Kepala Sekolah , Kompetensi Profesional Dan Etos Kerja Terhadap Motivasi Kerja Guru Sd Gugus V Kecamatan Seririt. E-Journal Program Pascasarjana Universitas Pendidikan Ganesha, 6(1).

Lie, D., Sherly, S., Dharma, E., \& Sudirman, A. (2019). The Impact of Work Discipline and Work Ethic on the Teacher Performance of Sultan Agung Pematangsiantar Private Middle School Teachers T.A. 2018/2019. International Journal of Business Studies, 3(3), 125-135. https://doi.org/10.32924/ijbs.v3i3.83

Luthans, Fred. 2006. Perilaku Organisasi. Edisi Kesepuluh. Yogyakarta: ANDI.

Mamminanga, I. (2019). Pengaruh Etos Kerja Terhadap Kinerja Pegawai Pada Kantor Kecamatan Maniangpajo Kabupaten Wajo. Jurnal Ilmiah Administrasi Publik Dan Bisnis, 1(1), 11-21.

Mianto, A., Hendriani, S., \& Efni, Y. (2018). Pengaruh Motivasi dan Iklim Psikologis Terhadap Kinerja Pegawai Pada Kantor Pelayanan Pajak Madya Pekanbaru dengan Kepuasan Kerja Sebagai Variabel Intervening. Jurnal Tepak Manajemen Bisnis, 10(3), 425-444.

Mondy R, Wayne. 2008. Manajemen Sumber Daya Manusia. Jilid I, Edisi 10. Jakarta: Erlangga.

PP Nomor 46 Tahun 2011, Tentang Penilaian Pelaksanaan Pekerjaan PNS.

Putra, R. E., \& Prasetya, A. (2018). Pengaruh Program Keselamatan dan Kesehatan Kerja Terhadap Produktifitas Kerja Karyawan. Jurnal Administrasi Bisnis, 56(2), 153159.

Ritonga, S. (2019). Pengaruh Iklim Organiasi dan Etos Kerja terhadap Kinerja Karyawan PT. Charoen Pokphand Indonesia Medan dengan Motivasi sebagai Variabel Intervining. Jurnal Manajemen Dan Bisnis, 19(1), 14-27.

Robbins, Stephen P dan Timothy A. Judge. 2008. Manajemen. Edisi 11. Jakarta: Salemba Empat.

Rosmawati, S., \& Jermawinsyah, A. (2018). Pengaruh Etos Kerja, Disiplin Kerja Dan Komitmen Karyawan Terhadap Kinerja Karyawan Pada Puskesmas Aro Kecamatan Muara Bulian. Eksis: Jurnal Ilmiah Ekonomi Dan Bisnis, 9(2), 153. 
https://doi.org/10.33087/eksis.v9i2.143

Sah, K., Mulyasa, E., \& Hanafiah, N. (2018). Pengaruh Gaya Kepemimpinan Dan Motivasi Kerja Terhadap Kinerja Pegawai. Fokus Manajemen Pendidikan, 2(1), 37-44. https://doi.org/10.21009/jmp.02103

Sahir, H. S. et al. 2020. Gagasan Manajemen. Cetakan 1. Medan: Yayasan Kita Menulis

Simanjuntak, P. A. (2020). Pengaruh Etos Kerja, Kepuasan Kerja, Sikap Kerja Dan Motivasi Kerja Terhadap Kinerja Pegawai Pada Kantor Pelayanan Pajak Pratama Medan Polonia. Manajemen Bisnis Jurnal Magister Manajemen, 2(1), 48-55.

Syahputra, M. E., Bahri, S., \& Rambe, M. F. (2020). Pengaruh Kepemimpinan , Disiplin dan Motivasi Terhadap Kinerja Pegawai Dinas Tarukim Labura. Jurnal Pamator, 13(1), 110-117.

Takwim, R. I. I. M. (2012). Pengaruh Konflik Dan Motivasi Kerja Terhadap Etos Kerja Dan Implikasinya Pada Kinerja Karyawan. Jurnal Riset Manajemen, 1(1), 84-95. https://doi.org/10.17509/image.v1i1.2324

Tasmara.Toto. 2002. Membudayakan Etos Kerja Islami. Jakarta: Gema Insani Press. 